\title{
Validation and Optimization of Heat and Mass Transfer Model for Mushroom Convection Drying
}

\author{
Huimin Shan ${ }^{1}$, and Kongqing $\mathrm{Li}^{1}$ \\ ${ }^{1}$ School of Civil Engineering, Hunan University of Science and Technology, Xiangtan Hunan 411201, China
}

\begin{abstract}
In order to solve the problems of time consuming, energy consumption and low simulation accuracy in the hot air-drying system of food drying. Using computational fluid dynamics (CFD) to simulate the drying process of mushrooms can provide a reference for its technology research and development (R\&D). The porous media approach was used to model the flow resistance offered by the mushroom. The resistance coefficient and porosity were determined through the experiments. Different air supply ways (wind speed, temperature, fresh air volume, reverse air supply period) were simulated and two optimize ways were suggested according the shortest possible drying time. The simulation results are in good agreement with the experimental results. The air supply way of periodic with reverse (SMPR), which means timed alternate the direction of air flow, or the way of mix in fresh air intermittently can effectively shorten the drying time. Considering comprehensively, the optimal air supply way was the mix in fresh air intermittently with fresh air accounts for $30 \%$ or SMPR with the period of $2 \mathrm{~h}$ under the condition of the hot air temperature of $55^{\circ} \mathrm{C}$ and wind velocity of $0.6 \mathrm{~m} / \mathrm{s}$.
\end{abstract}

\section{Introduction}

Drying is one of the most energy-consuming and complex devices. There are still many deficiencies in hot air-drying technology for food, such as long process time, large energy consumption, poor uniformity, etc. Modeling technology has great potential to develop drying technology. It can optimize the current drying equipment design and drying process. Moreover, the numerical model has cost advantages in industry, such as no additional lab space, maintenance and technical personnel operating equipment, reducing measurement and lab fullscale testing. Drying model plays an important role in drying technology $R \& \mathrm{D}^{[1]}$.

The accuracy of dry simulation based on CFD is limited, which is mainly due to the modeling method and technology ${ }^{[2-4]}$. The drying process is related to the knowledge of material properties, which are not well known. These have a great influence on the accuracy of the drying model results ${ }^{[5-7]}$. Increasing the reliability and confidence of numerical models can promote the development of drying technology. For specific drying materials, drying ways has to be guided by experience and validation studies.

\section{Drying experiment}

\subsection{Properties experiment}

The drying effect varies with the material properties. Mushroom material properties: heat capacity at constant pressure is $1800 \mathrm{~J} /(\mathrm{kg} \cdot \mathrm{K})$; The diffusion coefficient takes an average of $10^{-9} \mathrm{~m}^{2} / \mathrm{s}$; Density is $860 \mathrm{~kg} / \mathrm{m}^{3}$; Thermal conductivity is $0.515 \mathrm{~W} /(\mathrm{m} \cdot \mathrm{K})^{[8]}$.

\subsubsection{Materials and instruments}

Fresh mushrooms samples were procured from local vegetable market and had a moisture content of about $80 \%$. The air heated by an electric heater (PTC) was fed into drying box with a volume of $14 \times 14 \times 14 \mathrm{~cm}^{3}$ by an axial flow fan (FD3-2). The inlet and outlet were both $14 \times 14 \mathrm{~cm}^{2}$ with opposites. During the experimental process, a thermal anemometer (TSI-9565, USA) was used to measure the wind speed at the inlet of the drying box. A compensated micromanometer (YJB-1500) was used to measure the pressure difference between the inlet and outlet of the drying box, and a thermocouple temperature control box (1A1-K) was used to control the temperature of the supply air. The moisture loss of the sample was recorded at every $1 \mathrm{~h}$ interval by a precision electronic balance weighing (BSM-220.4).

\subsubsection{Experimental scheme}

\subsubsection{Resistance experiment}

The porous media approach was used to model the flow resistance offered by the mushroom. The resistance is derived from experimental data of pressure drop at 
different velocity of air passing by. The relationship between pressure drops and wind speed was shown into Fig. 1. Fitting result and the goodness are also presented in it. The correlation coefficient of the fit $\mathrm{R}^{2}$ is 0.9691 .

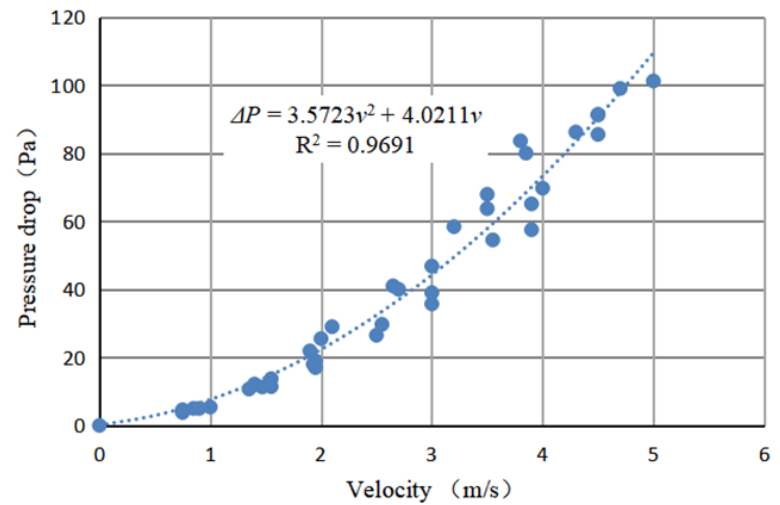

Figure 1. Air Supply Speed at the Inlet and Pressure Drop across the Drying Box

The influence of porous media is modelled by specifying a momentum source term in the standard fluid flow Equation (1) as:

$$
S_{i}=-\left(\frac{\mu}{\alpha} v_{i}+\frac{1}{2} C_{2} \rho|v| v_{i}\right)
$$

Where, $v$ is the velocity of air, $\mathrm{m} / \mathrm{s} ; \mu$ is the viscosity, $\mathrm{Pa} \cdot \mathrm{s} ; \rho$ is the density of air, $\mathrm{kg} / \mathrm{m}^{3} ; \Delta P$ is the pressure drop, $\mathrm{Pa}$. where $\alpha$ is the permeability $\left(1 / \alpha=1604589 \mathrm{~m}^{-2}\right)$ and $\mathrm{C}_{2}$ is the inertial resistance factor. $\left(\mathrm{C}_{2}=41.6 \mathrm{~m}^{-1}\right)$. The viscosity resistance drag coefficients and inertial drag coefficients are obtained by sorting out formula (1) and fitting results.

\subsubsection{Porosity experiments}

Since the whole box space were regarded as a porous medium in the following simulations. The procedure of porosity measurement was as follows: the initial apparent volume of the mushroom in its natural state was $\mathrm{V}$ which can be approximately considered as the volume of the box.
The actual volume of mushrooms was measured by drainage method: the mushrooms were reasonably laid in a thin plastic bag, and the air in the bag was discharged with the pressure of water, then the actual volume of mushrooms $\mathrm{Vi}$ was measured. The porosity of can be calculated by:

$$
P=\frac{V-V_{\mathrm{i}}}{V}
$$

The porosity $\mathrm{P}$ is divided into four stages according to the drying time, as shown in Table 1.

Table1. The porosity of mushrooms varies with time

\begin{tabular}{cccc}
\hline $\begin{array}{c}\text { Drying } \\
\text { time / }(\mathrm{h})\end{array}$ & $\begin{array}{c}\text { Total volume of } \\
\text { the box } /\left(\mathrm{m}^{3}\right)\end{array}$ & $\begin{array}{c}\text { Actual volume of } \\
\text { mushroom } /\left(\mathrm{m}^{3}\right)\end{array}$ & porosity \\
\hline $0 \sim 1$ & $2.74 \times 10^{-3}$ & $1.37 \times 10^{-3} \sim 1.26 \times 10^{-3}$ & 0.5 \\
$1 \sim 4$ & $2.74 \times 10^{-3}$ & $1.23 \times 10^{-3} \sim 1.13 \times 10^{-3}$ & 0.55 \\
$4 \sim 6$ & $2.74 \times 10^{-3}$ & $1.10 \times 10^{-3} \sim 9.01 \times 10^{-4}$ & 0.6 \\
$>6$ & $2.74 \times 10^{-3}$ & $8.51 \times 10^{-4} \sim 8.11 \times 10^{-4}$ & 0.69 \\
\hline
\end{tabular}

\subsection{Drying test and model}

\subsubsection{Drying parameters}

The experiment was carried out in winter, and the moisture content was not controlled due to the small difference in humidity in the air. Experimental conditions are shown in Table 2:

Table2. Mushroom drying experimental conditions

\begin{tabular}{ccccc}
\hline NO. & $\begin{array}{c}\text { Dry-bulb } \\
\text { temp. } /\left({ }^{\circ} \mathrm{C}\right)\end{array}$ & $\begin{array}{c}\text { Wet-bulb } \\
\text { temp. } /\left({ }^{\circ} \mathrm{C}\right)\end{array}$ & $\begin{array}{c}\text { Relative } \\
\text { humidity } /(\%)\end{array}$ & $\begin{array}{c}\text { Air supply } \\
\text { velocity } /(\mathrm{m} / \mathrm{s})\end{array}$ \\
\hline 1 & 45 & 20 & 7.36 & 1 \\
2 & 55 & 23 & 4.6 & 1 \\
3 & 65 & 26 & 3.31 & 1 \\
\hline
\end{tabular}

Table 4. Modified formula of drying kinetics model at different temperatures

\begin{tabular}{ccc}
\hline Temp. of supply air $/\left({ }^{\circ} \mathrm{C}\right)$ & Formula of drying kinetics model & $\mathrm{R}^{2}$ \\
\hline 45 & $\mathrm{M}_{\mathrm{t}}=3.27 \exp \left(-(7.83 \mathrm{E}-07) \times \mathrm{t}^{1.47}\right)+1.59 \exp \left(-(9.2 \mathrm{E}-06) \times \mathrm{t}^{1.47}\right)$ & 0.99995 \\
55 & $\mathrm{M}_{\mathrm{t}}=3.71 \exp \left(-(3.71 \mathrm{E}-06) \times \mathrm{t}^{1.26}\right)+1.15 \exp \left(-(9.13 \mathrm{E}-05) \times \mathrm{t}^{1.26}\right)$ & 0.99989 \\
65 & $\mathrm{M}_{\mathrm{t}}=-39.39 \exp \left(-(2.18 \mathrm{E}-04) \times \mathrm{t}^{0.91}\right)+44.24 \exp \left(-(2.29 \mathrm{E}-04) \times \mathrm{t}^{0.91}\right)$ & 0.99971 \\
\hline
\end{tabular}

\subsubsection{Selection and calculation of hot-air drying models}

Calculation formula of dry base moisture content $\left(\mathrm{M}_{\mathrm{t}}\right)$ :

$$
M_{\mathrm{t}}=\frac{W_{t}-G}{G}
$$

Where, $W_{t}$ is the material mass at any time point in the drying process, $g$; $G$ is the mass of the material when it is completely dried (that is the dry base mass).

Match the experimental results with the commonly used drying model ${ }^{[9-17]}$ (as shown in Table 3). Finally, it was found that Hii model was the most consistent with the law of mushroom drying. Fig. 2 and Table 4 show the model fitting results of $M_{t}$ changes with time under different drying temperatures. 
Table 3. Kinetic model of mushroom drying

\begin{tabular}{ccc}
\hline NO. & The model name & Model formulation \\
\hline 1 & Newton & $\mathrm{M}_{\mathrm{t}}=\exp (-\mathrm{k} \mathrm{t})$ \\
2 & Henderson and Pabis & $\mathrm{M}_{\mathrm{t}}=\mathrm{a} \exp (-\mathrm{k} \mathrm{t})$ \\
3 & Page & $\mathrm{M}_{\mathrm{t}}=\exp \left(-\mathrm{k} \mathrm{t}^{\mathrm{n}}\right)$ \\
4 & Logarithmic & $\mathrm{M}_{\mathrm{t}}=\mathrm{a} \exp (-\mathrm{k} \mathrm{t})+\mathrm{c}$ \\
5 & Two term model & $\mathrm{M}_{\mathrm{t}}=\mathrm{a} \exp (-\mathrm{k} \mathrm{t})+\mathrm{b} \exp (-\mathrm{g} \mathrm{t})$ \\
6 & Verma et al. & $\mathrm{M}_{\mathrm{t}}=\mathrm{a} \exp (-\mathrm{k} \mathrm{t})+(1-\mathrm{a}) \exp (-\mathrm{g} \mathrm{t})$ \\
7 & Midili-kucuk & $\mathrm{M}_{\mathrm{t}}=\mathrm{a} \exp \left(-\mathrm{k} \mathrm{t} \mathrm{t}^{\mathrm{n}}\right)+\mathrm{b} \mathrm{t}$ \\
8 & Wang and smith & $\mathrm{M}_{\mathrm{t}}=1+\mathrm{a} \mathrm{t}+\mathrm{b} \mathrm{t} \mathrm{t}^{2}$ \\
9 & Hii & $\mathrm{M}_{\mathrm{t}}=\mathrm{a} \exp \left(-\mathrm{k} \mathrm{t} \mathrm{t}^{\mathrm{n}}+\mathrm{b} \exp \left(-\mathrm{g} \mathrm{t} \mathrm{t}^{\mathrm{n}}\right)\right.$ \\
\hline
\end{tabular}

Where, $\mathrm{t}$ is time, $\mathrm{M}_{\mathrm{t}}$ is dry base moisture content, others are constants.

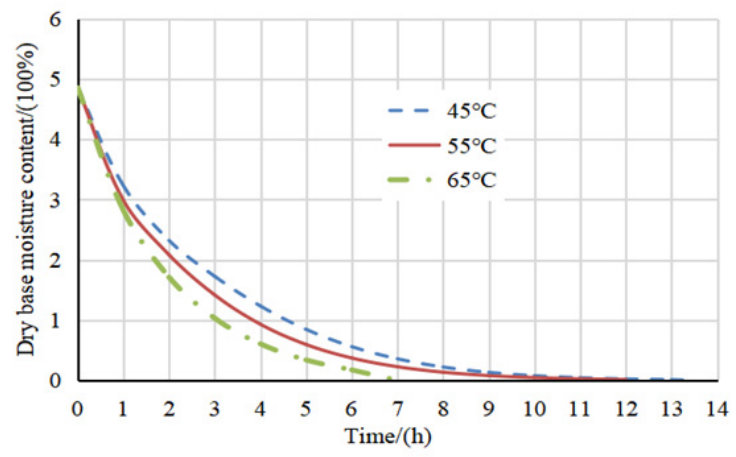

Figure 2. Relationship between Dry Base Moisture Content and Time at Different Temperatures

\section{Model establishment}

\subsection{Numerical model}

The turbulence model used in the air flow simulation is the $\mathrm{k}-\mathcal{E}$ model ${ }^{[18]}$. In the dynamic equilibrium state of water absorption and resolution of mushroom, the main factors that affect the amount of water released or absorbed by mushroom include temperature and the concentration of water vapor in the surrounding air. The concentration of water vapor in the air is equal to the sum of the concentration of water vapor in the air and the water vapor evaporated from the mushroom during the drying process. Vapor concentration equation is as follow:

$$
\frac{\partial \mathrm{c}}{\partial T}=D_{A}\left(\frac{\partial^{2} \mathrm{c}}{\partial x^{2}}+\frac{\partial^{2} \mathrm{c}}{\partial y^{2}}+\frac{\partial^{2} \mathrm{c}}{\partial z^{2}}\right)-\rho_{S} \frac{1-V_{k}}{V_{k}} \frac{\partial M}{\partial t}
$$

The basis for establishing the temperature equation of dry-base matter is that the temperature change of mushrooms is composed of two parts: one is the heat exchange between mushrooms and hot air, the other is the heat consumed by the evaporation of water vapor in mushrooms. Its equation is as follow:

$$
\frac{\partial T}{\partial \mathrm{t}}=\frac{k}{\rho c}\left(\frac{\partial^{2} T}{\partial x^{2}}+\frac{\partial^{2} T}{\partial y^{2}}+\frac{\partial^{2} T}{\partial z^{2}}\right)+\frac{q}{\rho} \frac{\partial M}{\partial t}
$$

The calculation formula of mass transfer rate is:

$$
\frac{\partial M}{\partial t} \approx \frac{\Delta M}{\Delta t}
$$

The mass of water vapor escaping is the product of the change in dry base moisture content and the dry base mass:

$$
\Delta M=\Delta M_{\mathrm{t}} \times \mathrm{G}
$$

In the simulated drying process, the parameters of each cell are different. Therefore, when calculating the dry basis moisture content of each cell, interpolation should be used to calculate the dry basis moisture content formula with the known temperatures:

$$
M_{\mathrm{t}}=M_{t_{1}}-\frac{M_{t_{1}}-M_{\mathrm{t}_{2}}}{t_{1}-t_{2}}\left(t_{1}-t_{0}\right)
$$

Where, $D_{A}$ is the diffusion coefficient of water vapor in the air, $\mathrm{m}^{2} / \mathrm{s} ; V_{k}$ is the volume occupied by air in the porous medium, $\mathrm{m}^{3} ; T$ is the temperature of the mushroom, $\mathrm{K}$; $c$ is water vapor concentration, $\mathrm{kg} / \mathrm{m}^{3} ; t$ is drying time, $\mathrm{s} ; \rho_{s}$ is wet density of mushroom, $\mathrm{kg} / \mathrm{m}^{3} ; \rho$ is the apparent density of mushrooms, $\mathrm{kg} / \mathrm{m}^{3} ; k$ is thermal conductivity, $\mathrm{W} /(\mathrm{m} \cdot \mathrm{K}) ; \Delta M$ is the amount of water vapor escaped, $\mathrm{kg}$; $M_{t 1}, M_{t 2}$ are the moisture content of the dry basis when the temperature is $t_{1}$ and $t_{2}$, respectively, where $t_{1}$ and $t_{2}$ are the two temperature values closest to $45^{\circ} \mathrm{C}, 55^{\circ} \mathrm{C}$ and $65^{\circ} \mathrm{C}$ for $\mathrm{t}_{0}$.

\subsection{Physical model}

The simulation target was a three-dimensional model of the drying box and transient simulations were carried out. The dimension of the box was $3 \mathrm{~m}$ length, $2 \mathrm{~m}$ width by $2 \mathrm{~m}$ high (along $\mathrm{x}$-axis, $\mathrm{z}$-axis and $\mathrm{y}$-axis, respectively). $0 \mathrm{~m} \sim 3 \mathrm{~m}$, z-axis: $-1 \mathrm{~m} \sim 1 \mathrm{~m}$; y-axis: $0 \mathrm{~m} \sim 2 \mathrm{~m}$. The entrance was located in the $y z$ plane with $x=0 \mathrm{~m}$, and the exit was located in the $y z$ plane with $x=3 \mathrm{~m}$. Three sets of simulation experiments with the initial temperature of $17^{\circ} \mathrm{C}$ were performed.

The air supply parameters set in the simulations are consistent with those in the experiments. In order to reduce the drying time, energy consumption, and avoid excessive drying, the relative humidity at the end of the drying box needs to be reduced by PRAS or mix in fresh air. Three kinds of simulations have been performed in this paper.

- The first kind one was conducted under three set temperatures of $45^{\circ} \mathrm{C}, 55^{\circ} \mathrm{Cand} 65^{\circ} \mathrm{C}$ and three wind velocities of $0.4 \mathrm{~m} / \mathrm{s}, 0.6 \mathrm{~m} / \mathrm{s}$ and $0.8 \mathrm{~m} / \mathrm{s}$, in which temperature and velocity of hot drying air at the inlet were kept constant in the whole process of drying.

- The second kind was to add a way to mix in fresh air on the basis of the first kind, it was conducted under three fresh air ratio of $20 \%, 30 \%, 40 \%$, in which the mixed fresh air temperature is $5^{\circ} \mathrm{C}$, and moisture content is $4.1 \mathrm{~g} / \mathrm{kg}$, and mixed air supply 10 minutes for every 1 hour.

- The third kind was conducted under three set temperatures of $45^{\circ} \mathrm{C}, 55^{\circ} \mathrm{C}$ and $65^{\circ} \mathrm{C}$, three wind velocities of $0.4 \mathrm{~m} / \mathrm{s}, 0.6 \mathrm{~m} / \mathrm{s}$ and $0.8 \mathrm{~m} / \mathrm{s}$, and three period of $2 \mathrm{~h}, 3 \mathrm{~h}$ and $4 \mathrm{~h}$, in which air supply direction changed every half period.

Reduce unnecessary workload through orthogonal experiment, 9 groups of simulation experiments were needed for each case. 


\section{Result and analysis}

\subsection{Accuracy analysis of simulation}

As shown in Figure 3. When the temperature was $45^{\circ} \mathrm{C}$, $55^{\circ} \mathrm{C}$ and $65^{\circ} \mathrm{C}$, the maximum relative errors between the experiment and simulation were $0.52 \%, 3.35 \%$ and $1.36 \%$, respectively, in the drying process. The error tends to increase over drying time. The reasons may be caused by iterative convergence error and discrete error in the simulation process. In addition, the error increases as temperature increasing. This was because the increase of temperature in the actual drying process leads to a large amount of shrinkage of the mushroom, and the drying rule of the different moisture between surface and interior causes a large change in the diffusion rate of internal moisture to the surface. And the diffusion coefficient of this model was averaged. The simulated drying time at $45{ }^{\circ} \mathrm{C}$, $55{ }^{\circ} \mathrm{C}$ and $65^{\circ} \mathrm{C}$ was $13.4 \mathrm{~h}, 12 \mathrm{~h}$ and $6.8 \mathrm{~h}$, respectively, which was similar to the experimental results.

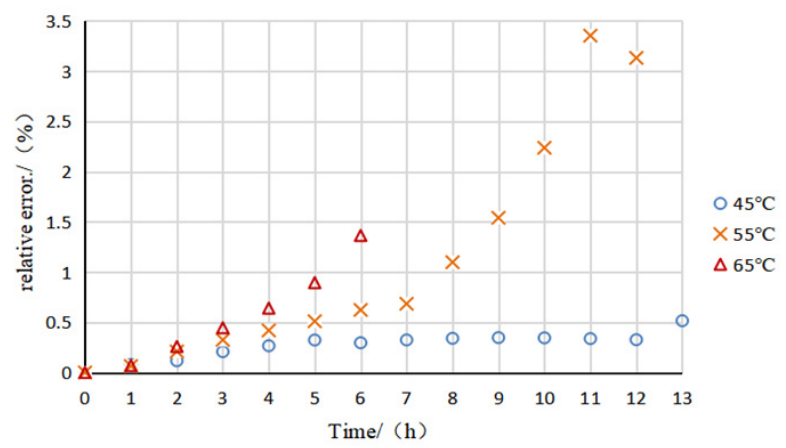

Figure 3. Relative Error between Experimental and Simulated Values of Dry Base Moisture Content of Mushrooms Per Hour at 45、55、65 ${ }^{\circ} \mathrm{C}$

\subsection{Optimization of air supply scheme}

The results of the two simulation methods are used as typical examples: one was conducted under temperature of $55^{\circ} \mathrm{C}$, wind speed of $0.8 \mathrm{~m} / \mathrm{s}$, fresh air ratio of $30 \%$, and the other was under temperature of $45^{\circ} \mathrm{C}$, wind speed of $0.4 \mathrm{~m} / \mathrm{s}$, period of $2 \mathrm{~h}$ (other similar figures were omitted due to space limitation). The drying box were divided into 9 parts along the direction of air supply. The dry basis moisture content of each part at different time is shown in Fig. 4 and Fig. 5. The initial decrease rate of dry basis moisture content is fast, but with the process of drying, the time needed gradually becomes longer when the dry basis moisture content decreases by 1 . This is due to lower internal moisture content and a slower rate of water diffusion from interior region.

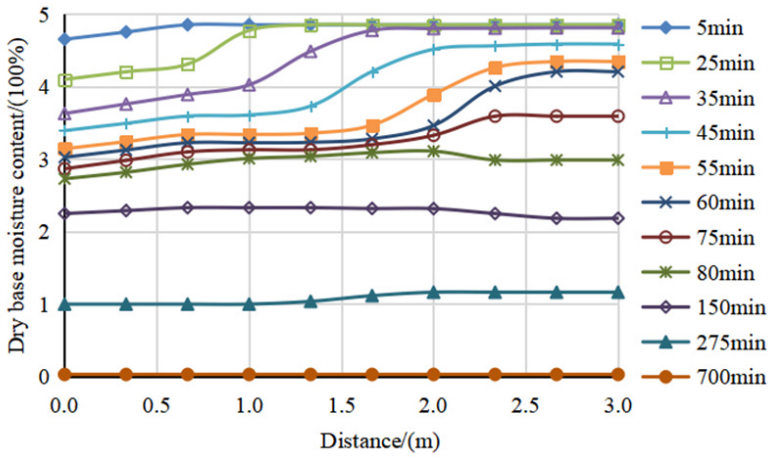

Figure 4. Dry Basis Moisture Content (Mt) at Different Time Points at method of periodic reverse the direction of air, in which was conducted under periodic of 2 hour, temperature of $45^{\circ} \mathrm{C}$ and wind velocity of $0.4 \mathrm{~m} / \mathrm{s}$

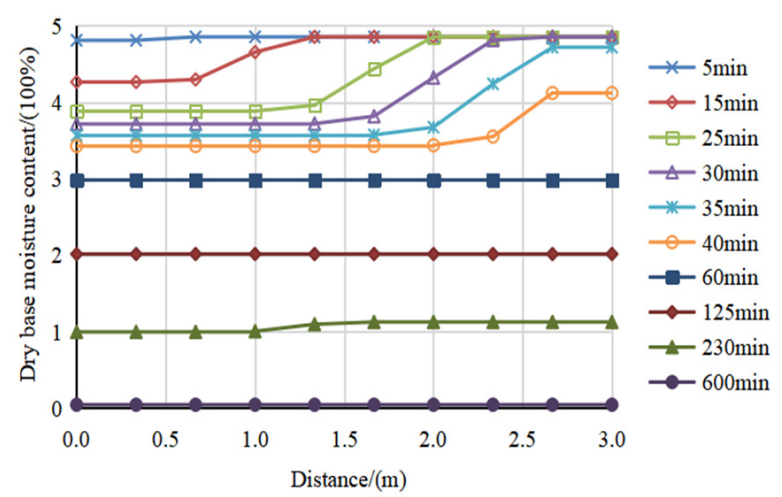

Figure 5. Dry Base Moisture Content (Mt) at Different Time Points at mix in Fresh Air, in which was conducted under Fresh Air Ratio of $30 \%$, temperature of $45^{\circ} \mathrm{C}$ and wind velocity of $0.4 \mathrm{~m} / \mathrm{s}$

For the direct air supply, the closer to the outlet, the higher dry basis moisture content (significantly at the initial drying stage), because the relative humidity of air is one of the main factors affecting the drying rate. Simulated physical model according to the industrial production needs of the stacking volume of mushroom. Mushrooms near the entrance have the priority of convective heat and humidity exchange. In this process the increase of moisture content in the air decreases their drying ability. Therefore, the method of periodic reverse air supply and introduce the fresh air with low humidity in time can not only ensure the uniformity of drying, but also reduce drying time and energy consumption.

The total drying time under different working condition is shown in Table 5.

Table 5. Summary of drying time under various conditions

\begin{tabular}{|c|c|c|c|c|c|}
\hline \multicolumn{2}{|c|}{$\begin{array}{c}\text { Air supply with } \\
\text { constant }\end{array}$} & \multicolumn{2}{|c|}{ Mix in fresh air } & \multicolumn{2}{|c|}{ SMPR } \\
\hline $\begin{array}{c}\text { Temp- } \\
\text { wind speed } \\
/\left({ }^{\circ} \mathrm{C}-\mathrm{m} / \mathrm{s}\right)\end{array}$ & $\begin{array}{l}\text { Drying } \\
\text { time } \\
/(\mathrm{min})\end{array}$ & $\begin{array}{l}\text { Temp-wind } \\
\text { speed-fresh } \\
\text { air ratio } \\
/\left({ }^{\circ} \mathrm{C}-\mathrm{m} / \mathrm{s}-\%\right)\end{array}$ & $\begin{array}{l}\text { Drying } \\
\text { time } \\
/(\min )\end{array}$ & $\begin{array}{l}\text { Temp-wind } \\
\text { speed-period } \\
/\left({ }^{\circ} \mathrm{C}-\mathrm{m} / \mathrm{s}-\mathrm{h}\right)\end{array}$ & $\begin{array}{l}\text { Drying } \\
\text { time } \\
/(\mathrm{min})\end{array}$ \\
\hline $45-0.4$ & 730 & $45-0.4-20$ & 695 & $45-0.4-2$ & 700 \\
\hline $45-0.6$ & 720 & $45-0.6-30$ & 720 & $45-0.6-4$ & 700 \\
\hline $45-0.8$ & 700 & $45-0.8-40$ & 700 & $45-0.8-3$ & 690 \\
\hline $55-0.4$ & 690 & $55-0.4-20$ & 650 & $55-0.4-3$ & 640 \\
\hline
\end{tabular}




\begin{tabular}{llllll}
$55-0.6$ & 670 & $55-0.6-30$ & 600 & $55-0.6-2$ & 600 \\
$55-0.8$ & 670 & $55-0.8-40$ & 600 & $55-0.8-4$ & 600 \\
$65-0.4$ & 375 & $65-0.4-20$ & 370 & $65-0.4-4$ & 365 \\
$65-0.6$ & 370 & $65-0.6-30$ & 370 & $65-0.6-3$ & 365 \\
$65-0.8$ & 365 & $65-0.8-40$ & 365 & $65-0.8-2$ & 365 \\
\hline
\end{tabular}

The method of periodic reverse the direction of air can solve the situation that the relative humidity of the air in the exit section is higher than that in the entrance section, as shown in Fig. 4 after 80 mins later, which will lead to low drying speed at the exit section and excessive drying at the entrance section. The method of introducing fresh air can reduce the relative humidity of air from the source, increase the concentration difference and water vapor partial pressure difference, promote the overflow of water, and reduce the drying time.

Temperature plays a more important role on drying rate than wind speed does. At the same temperature, the higher wind speed, the shorter drying time, but it is not obvious. At the same wind speed, the higher the temperature, the faster the drying rate is, and it is more significant. The main reason is that the temperature and enthalpy of mushrooms increase during the drying process, which can promote the evaporation of water. However, temperature will affect the shrinkage degree of the material, and the higher temperature, the greater shrinkage, as shown in Figure 6. The shrinkage of $65^{\circ} \mathrm{C}$ is obvious, and the difference between $45^{\circ} \mathrm{C}$ and $55^{\circ} \mathrm{C}$ is small. Therefore, the optimal working condition is temperature of $55^{\circ} \mathrm{C}$, wind speed of $0.6 \mathrm{~m} / \mathrm{s}$, fresh air ratio of $30 \%$ and reverse air supply with a period of 2 hours, both of which are shortened by $70 \mathrm{~min}$.
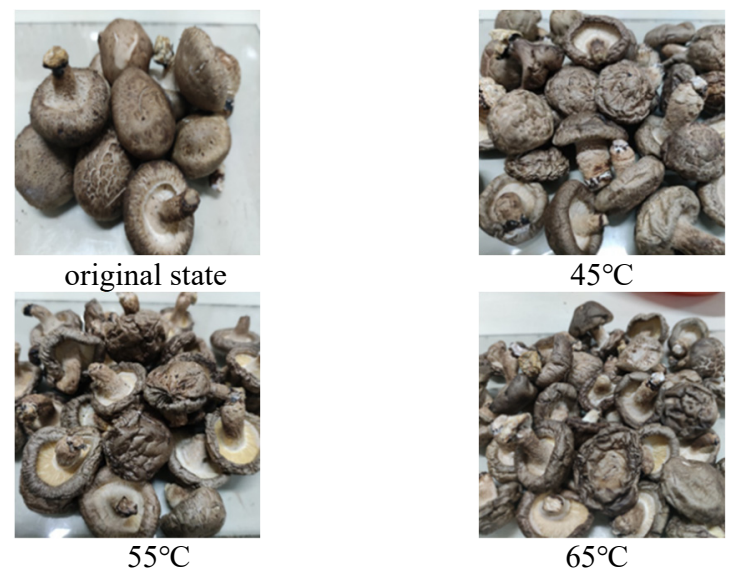

Figure 6. The Original State of Mushrooms and the State at Each Temperature When Drying Completely

\section{Conclusions}

Based on the mechanism of heat and moisture transfer and drying characteristics of mushrooms, a drying model of mushrooms with high accuracy was established. The simulation results can guide mushroom production practice. This simulation method provides a new idea for other food drying industry production and has a reference significance. The contents are as follows:
- Measure and calculate mushroom physical parameters: resistance coefficient, porosity.

- Drying kinetics model: according to the experimental results and the commonly used drying kinetics model, the Hii model has the highest fitting degree, $\mathrm{R}^{2}>0.999$.

- A new mathematical calculation model was proposed, and the UDF program was coupled to the CFD. The maximum relative error between the experimental and simulation results was $3.35 \%$.

- Three air supply ways are simulated: air supply with constant, mix in fresh air and SMPR. Drying time, uniformity, appearance shrinkage, energy saving and other factors should be considered. Analytically there are two optimal dry conditions. One is mix in fresh air, in which is conducted under temperature of $55^{\circ} \mathrm{C}$, wind speed of $0.6 \mathrm{~m} / \mathrm{s}$ and fresh air ratio of $30 \%$. The other is SMPR. It is conducted under temperature of $55^{\circ} \mathrm{C}$, wind speed of $0.6 \mathrm{~m} / \mathrm{s}$ and period of 2 hours. Both of them can shorten the drying time by 70 minutes.

\section{References}

1. T. Defraeye, Appl. Energy 131, 323-344 (2014)

2. T. Norton, D.W.Sun, Trends in Food ence \& Technology 17,600-620 (2006)

3. M. Casey, T. Wintergerste, Best Practice Guidelines, (2000).

4. D. Lacasse, R. Turgeon, D. Pelletier, Int. J. Therm. Sci. 43, 925-938 (2004)

5. A.K. Datta, J. Food Eng. 80, 96-110 (2007)

6. A.K. Datta, Compr. Rev. Food. Sci. Food Saf. 7, 121129 (2008)

7. T. Gulati , A.K. Datta, J. Food Eng. 116, 483-504 (2013)

8. Z.Y.Zhang, Y.Q. Li, C.H. Liu,et al. Food Sci. 623, 239-246 (2020)

9. A. Ayensu, Sol. Energy 59, 121-126 (1997)

10. M. Kashaninejad, A. Mortazavi, A. Safekordi, et al, J. Food Eng. 78, 98-108 (2007)

11. V.T.Karathanos, V.G. Belessiotis, J. Agr. Eng. Res. 74, 355-361 (1999)

12. I. Doymaz, J. Food Eng. 65, 205-209 (2004)

13. Z. Wang, J. Sun, X. Liao, et al, Food Res. Int. 40, 3946 (2007)

14. X.H. Guo, C.Y. Xia, Y.R Tan, et al, J. Integr. Agric. 13, 207-216 (2014)

15. A. Midilli, H. Kucuk, Energy Conv. Manag. 44, 11111122 (2003)

16. C.Y. Wang, R.P. Singh, (1978)

17. C.L. Hii, C.L. Law, M. Cloke, J. Eng. Sci. Tech. 3 (2008)

18. X.T. Li, B. Zhao, Numerical simulation of indoor air flow(CMP, Beijing, 2009) 